\title{
Perception of and Preference for Rural Built Environment of Rural Residents: Evidence from Sichuan
}

\author{
Yuting Zhang ${ }^{1}$, Yibin $\mathrm{Ao}^{1 *}$, Kun Huang ${ }^{1}$, Yan Wang ${ }^{2}$, Yunfeng Chen ${ }^{3}$, Xun Zhou ${ }^{1}$ \\ ${ }^{1}$ College of Environment and Civil Engineering, Chengdu University of Technology, Chengdu, Sichuan China, 610059 \\ ${ }^{2}$ Department of Construction Management, Sichuan College of Architectural Technology, Deyang, Sichuan China, 618000 \\ ${ }^{3}$ School of Construction Management Technology, Purdue Polytechnic Institute, Purdue University, West Lafayette, \\ Indiana, USA 47907
}

\begin{abstract}
Rural areas are undergoing tremendous changes due to rapid urbanization and new construction. However, few studies have investigated the perspectives of local residents on the changing landscape. This study investigates the aforementioned phenomenon via field surveys conducted in seven villages and townships in Sichuan Province. Factor analysis was performed on 352 valid questionnaires to analyze the perceptions of and preferences for the built environment of rural residents. Each analysis extracted 5 factors from 20 variables. The comparative analysis identified three common factors, namely, convenient transportation, public environment and roads, which influenced the perceptions on and preferences for the rural built environment. However, the importance of each factor differed in terms of perception and preference. Results of the analysis and comparison highlight areas that can be improved and promoted in new rural construction. Suggestions for development and construction are provided to promote the progress of new countryside regions.
\end{abstract}

Keywords: rural area, built environment, perception, preference, factor analysis

\section{Introduction}

Agriculture, rural areas and farmers are three key issues that the Chinese government has focused on for nearly a decade (Cheng 2011). New urbanization and rural construction are long-term and arduous historical tasks in China (Chen 2014). The scientific development concept should be used as a guide to formulate a new concept of integrated urban-rural development that is conducive to solving the three aforementioned rural issues. In October 2005, the Fifth Plenary Session of the 16th Central Committee of the Communist Party of China officially proposed the strategic concept of building a new socialist countryside and clarified that new rural construction is a route map for national and regional development strategies in the next five years (Yang et al 2014). In recent years, the rural built environment has been undergoing considerable changes under the influence of rural revitalization strategic planning and the acceleration of the construction of new rural areas. In this study, the perception of the built environment is considered to be the satisfaction of local residents on the built environment. Meanwhile, the preference for the built environment is regarded as an effect of different environmental factors on the choice of new residences in the process of new rural development. On the basis of the rapid development of the new countryside, this study regards the different views of farmers on the built environment as a starting point and uses questionnaires to understand the rural residents' perceptions and preferences on the built environment. The analysis also indicates the need for further improvement under a built environment with different time and space. This study proposes a scientific basis and effective countermeasures for the government to solve relevant problems during the construction of new rural areas.

In the processes of rural urbanization and new rural construction, the built environment of rural China has changed in terms of time and space. Built environment factors are undoubtedly among the most extensively researched subjects in travel survey. The most cited land use factors are referred to as "Ds" (such as density, diversity, design, distance to public transportation, destination accessibility). The original "3Ds" identified by Cervero and Kockelman (1997) are density, diversity, and design. Destination accessibility and distance to transit later followed (Ewing and Cervero 2001, 2010, Ewing et al 2009). China's research on the effect of the built environment and its behavior remains in its infancy and has focused on firsttier cities (Wang and Zhou 2017). Dong et al (2011) selected high-rise buildings as research objects, conducted subjective evaluation of the built environment, and analyzed the built environment from the physiological and psychological

* Corresponding Author:Yibin Ao, email: aoyibin10@mail.cdut.edu.cn

Received October 19, 2018; Revised December 23, 2018; Accepted December 26, 2018; Available online January 31, 2019 
perspectives. Zhang et al (2017) asserted that a mixed and dense road network and a compact built environment exert a negative effect on the feeling of safety in residential areas. Therefore, a multilayer linear model was used to analyze the effect of the built environment of Chinese cities on the sense of residential security. Sun and Dan (2015) conducted questionnaire survey to study the effect of the built environment on the choice of commuting methods of Shanghai residents, thereby providing inspiration for urban transportation and planning. Ta et al (2015) studied the effect of the built environment on the use of cars in Beijing during residents' working days. Wu (2017) analyzed the influence of the urban built environment on the walking activities of Nanjing residents. Berke et al (2007) studied the relationship among walking accessibility, physical activity and obesity in King County, Washington. The effect of the built environment on residents' walking behavior differed in three distance buffer zones around the residential area. Hong et al (2014) found that commuter's travel is affected by the built environment in an urban area, but the correlation is minimal at the neighborhood scale. By contrast, the non-working travel of residents, particularly their daily travel behavior, is considerably affected by the built environment characteristics at the neighborhood scale. Cervero and $\mathrm{Wu}$ (1998) used the suburbanization of the San Francisco Employment Center as an example to analyze the impact of changes in the urban spatial structure on residents' transportation. The aforementioned literature describes the subjective feelings of residents regarding the built environment and the effect of the built environment on their travel choices or behavior. However, these studies have focused on city areas. Studies on rural residents' perception of and preference for the built environment are rare. Rural areas in China are being "urbanized" and are undergoing considerable changes under the background of the construction of a "new countryside." Hence, the rural built environment is a development endeavor that cannot be disregarded.

\section{Questionnaire Design and Reliability Test}

\subsection{Questionnaire survey}

The household survey was conducted in January 2018. The locations comprised typical villages, including Wugang in Ya'an, Dazhuang and Shangten in Neijiang, Shuangyan in Guanghan, Xinlong in Deyang, Dongxing Community in Pengzhou and Huojing Town in Qionglai. The Yanjing resettlement community and the Dongxing community are mature concentrated residential areas. Shangten New Village is a new rural area under construction. Dazhuang, Shuangyan, Wugang and Xinlong Villages are traditional scattered rural areas. Among the 413 distributed questionnaires, 374 valid questionnaires were returned. The effective recovery rate of the questionnaires was $90.56 \%$.

\subsection{Indicator selection and variable definition}

The questionnaire contains three parts, namely, "Basic situation of family and individual", "Building environment perception" and "Building environment preference." This study defined rural residents' perception of the built environment as their satisfaction with the existing residential environment. The built environment preference is defined as the degree of influence of different environmental factors on the choice of new housing for rural residents in the process of new rural development.

The built environment perception and preference survey used the same 20 variables. As it has shown in Table 1. Each variable was defined on a five-point Likert scale. The options for built environment perception have the following choices: "completely" (5), "yes" (4), "general" (3), "not" (2) and "not at all" (1) (Ji and Long 2010). The options for built environment preference have the following choices: "very important" (5), "important" (4), "general" (3), "unimportant" (2) and "not at all important" (1). Perception analysis was conducted on residents' satisfaction with the built environment under 20 variables. Preference analysis is the degree to which each factor influences residents' choice of new residence under the same 20 variables as perception analysis. Survey preferences can be used to analyze which factors are more likely to affect residents' choice of new housing.

Table 1. Definition of indicator variables

\begin{tabular}{cl}
\hline Variable & \multicolumn{1}{c}{ Definition } \\
\hline$X_{1}$ & It is convenient to go to school \\
\hline$X_{2}$ & It is convenient to go to market \\
\hline$X_{3}$ & It is convenient to go to city \\
\hline$X_{4}$ & $\begin{array}{l}\text { It is convenient to go to public transportation } \\
\text { stations (bus, subway, train station) }\end{array}$ \\
\hline$X_{5}$ & $\begin{array}{l}\text { It is convenient to go to a health center } \\
\text { (hospital, clinic) }\end{array}$ \\
\hline$X_{6}$ & There are good bike paths \\
\hline$X_{7}$ & Good walkway \\
\hline$X_{8}$ & $\begin{array}{l}\text { There are parks or other public open space } \\
\text { near the home }\end{array}$ \\
\hline$X_{9}$ & There is a wide public courtyard \\
\hline$X_{10}$ & There is sufficient parking \\
\hline$X_{11}$ & Complete road lighting \\
\hline$X_{12}$ & Village appearance is very good \\
\hline$X_{13}$ & $\begin{array}{l}\text { Public facilities maintenance service is very } \\
\text { good }\end{array}$ \\
\hline$X_{14}$ & It's safe to walk \\
\hline$X_{15}$ & It is safe for children to play outside \\
\hline$X_{16}$ & The living environment is quiet \\
\hline$X_{17}$ & Good neighborhood relationship \\
\hline$X_{18}$ & No economic difference \\
\hline$X_{19}$ & No crimes incident \\
\hline$X_{20}$ & No traffic incident \\
\hline
\end{tabular}




\subsection{Analysis methods}

Factor analysis evaluates abstract factors through specific indicators and explicit variables. The essence of factor analysis is the use of the linear combination of several common factors for the observed indicator values. The basic model of factor analysis introduced in Zhou et al (2016) is as follows:

$$
\mathrm{X}_{\mathrm{i}}=\mathrm{a}_{\mathrm{i} 1} \mathrm{~F}_{1}+\mathrm{a}_{\mathrm{i} 2} \mathrm{~F}_{2}+\ldots+\mathrm{a}_{\mathrm{ik}} \mathrm{F}_{\mathrm{k}}+\varepsilon_{\mathrm{i}},
$$

where $X_{i}$ is the $i$-th index $(i=1,2,3, \ldots, \mathrm{m}) ; F_{i}$ is the $j$ th common factor $(j=1,2, \ldots, \mathrm{k}) ; a_{i j}$ is the $i$-th indicator of the load on $j$ common factors, called the factor load; $\varepsilon_{i}$ is the special factor that affects only the index $X_{i} ; k$ is the number of common factors; and $m$ is the number of indicators.

The basic steps of factor analysis are (1) determine whether the original variables to be analyzed are suitable for factor analysis, (2) structure factor variables, (3) use the rotation method to make the factor analysis variables more interpretable, and (4) calculate the factor score (Wu 2014).

\subsection{Questionnaire reliability test}

SPSS Statistics was used to analyze the missing values in the 374 valid questionnaires. Little's missing completely at random (MCAR) test had a significant $(P)$ value of 0.07 . The hypothesis that the missing value was MCAR could not be rejected. Deleted the sample with missing values, the final number of questionnaires was 352 , then analysis again. The overall reliability test had a Cronbach $\alpha$ reliability coefficient of 0.878 , which indicated that the questionnaire exhibited high reliability and the results based on the questionnaire analysis were relatively reliable. The Kaiser-Meyer-Olkin (KMO) coefficient for judging sample adequacy was 0.822 , the empirical value was greater than 0.5 , and the $P$ value was 0.000 . The test results are significant, thereby indicating a certain correlation among the data and that the questionnaire is suitable for factor analysis.

\section{Empirical Results}

\subsection{Questionnaire statistical description}

From Table 2, 51.7\% of the rural population has six or more people per household and $77.5 \%$ of the households have one underage member. The highest level of family education is typically junior or senior high school. Given that males usually are out of their homes as migrant workers and also women exhibit higher enthusiasm toward the questionnaire, the number of female-answered questionnaires is $21 \%$ higher than that of male-answered questionnaires. The age range of the survey respondents is distributed evenly, and the education level is mostly junior high school and below, which may lead to a simple and direct perception of and preference for the built environment.

\subsection{Perception on the built environment}

Factor analysis was used to analyze the built environment perception portion of the questionnaire. The KMO coefficient of sample sufficiency is 0.838 , the empirical
Table 2. Respondents' family and individual information

\begin{tabular}{|c|c|c|}
\hline \multicolumn{2}{|c|}{ Indicator } & Sample size $(\%)$ \\
\hline \multirow{4}{*}{ Family size } & $\begin{array}{l}3 \text { or less family } \\
\text { members }\end{array}$ & $5.4 \%$ \\
\hline & 4 people & $20.5 \%$ \\
\hline & 5 people & $22.4 \%$ \\
\hline & 6 or more people & $51.7 \%$ \\
\hline \multirow{4}{*}{$\begin{array}{l}\text { Family } \\
\text { members } \\
\text { under } 18 \\
\text { years old }\end{array}$} & 1 or less & $77.5 \%$ \\
\hline & 2 & $19.0 \%$ \\
\hline & 3 & $2.6 \%$ \\
\hline & 4 or more & $0.9 \%$ \\
\hline \multirow{6}{*}{$\begin{array}{l}\text { Highest } \\
\text { education } \\
\text { level in the } \\
\text { family }\end{array}$} & $\begin{array}{l}\text { Elementary school } \\
\text { and below }\end{array}$ & $5.4 \%$ \\
\hline & Junior high school & $29.0 \%$ \\
\hline & High school & $33.5 \%$ \\
\hline & $\begin{array}{l}\text { Skills-related } \\
\text { training }\end{array}$ & $10.2 \%$ \\
\hline & Bachelor & $20.5 \%$ \\
\hline & $\begin{array}{l}\text { Master's degree or } \\
\text { above }\end{array}$ & $1.4 \%$ \\
\hline \multirow{6}{*}{$\begin{array}{l}\text { Annual } \\
\text { household } \\
\text { income }\end{array}$} & Less than $¥ 10,000$ & $3.7 \%$ \\
\hline & $¥ 10000$ - ¥50000 & $57.9 \%$ \\
\hline & $¥ 50000$ - ¥100000 & $29.9 \%$ \\
\hline & $¥ 100000$ - ¥150000 & $5.9 \%$ \\
\hline & $¥ 150000$ - ¥200000 & $1.5 \%$ \\
\hline & $\begin{array}{l}\text { More than } \\
¥ 200,000\end{array}$ & $1.1 \%$ \\
\hline \multirow{2}{*}{$\begin{array}{l}\text { Respondent's } \\
\text { gender }\end{array}$} & Male & $39.5 \%$ \\
\hline & Female & $60.5 \%$ \\
\hline \multirow{6}{*}{$\begin{array}{l}\text { Respondent's } \\
\text { age }\end{array}$} & $\begin{array}{l}60 \text { years old or } \\
\text { older }\end{array}$ & $21.0 \%$ \\
\hline & $50-59$ years old & $24.5 \%$ \\
\hline & 40-49 years old & $25.2 \%$ \\
\hline & 30-39 years old & $10.8 \%$ \\
\hline & 20-29 years old & $13.4 \%$ \\
\hline & 20 years old or less & $5.1 \%$ \\
\hline \multirow{6}{*}{$\begin{array}{l}\text { Respondent's } \\
\text { education }\end{array}$} & $\begin{array}{l}\text { Elementary school } \\
\text { and below }\end{array}$ & $42.3 \%$ \\
\hline & Junior high school & $31.8 \%$ \\
\hline & High school & $17.4 \%$ \\
\hline & $\begin{array}{l}\text { Skills-related } \\
\text { training } \\
\end{array}$ & $5.4 \%$ \\
\hline & Bachelor & $2.8 \%$ \\
\hline & Maters' and above & $0.3 \%$ \\
\hline
\end{tabular}

value is greater than 0.5 and significance is $P=0.000$. The analysis showed that the first five principal component eigenvalues were greater than 1 , and their cumulative contribution rate reached $61.95 \%$. The factor load of "No difference exists in the economic conditions among the neighborhoods $\left(\mathrm{X}_{18}\right)$ " on the common factor was less than 
$0.4(0.302)$. Thus, this factor was deleted, and factor analysis was repeated. After the deletion, the KMO coefficient for judging the sufficiency of the sample was 0.841 , the eigenvalues of the first five principal components were greater than 1 , the cumulative contribution rate reached $64.36 \%$, and the load of the index on the common factor was 0.4 . Hence, the first five common factors were selected. The maximum variance orthogonal rotation method was used to rotate factor loading.

\subsubsection{Common factor extraction}

Factor analysis was performed to extract common factors. The specific operation results are presented in Table 3.

Table 3. Total variance interpretation

\begin{tabular}{llrrrrrrr}
\hline & Variance & \multicolumn{7}{c}{ Component } \\
\cline { 2 - 8 } & & $\mathbf{1}$ & $\mathbf{2}$ & $\mathbf{3}$ & $\mathbf{4}$ & $\mathbf{5}$ & $\mathbf{6}$ & $\mathbf{7}$ \\
\hline \multirow{3}{*}{\begin{tabular}{l} 
Initial eigenvalue \\
\cline { 2 - 8 }
\end{tabular}} & Total & 5.672 & 2.549 & 1.662 & 1.288 & 1.056 & 0.910 & 0.746 \\
\cline { 2 - 8 } & Percentage of variance & 29.854 & 13.418 & 8.748 & 6.780 & 5.556 & 4.791 & 3.925 \\
\cline { 2 - 8 } $\begin{array}{l}\text { Extract the sum } \\
\text { of squared loads }\end{array}$ & Cumulative \% & 29.854 & 43.272 & 52.020 & 58.800 & 64.356 & 69.147 & 73.071 \\
\hline \multirow{2}{*}{$\begin{array}{l}\text { Sum of squared } \\
\text { rotational loads }\end{array}$} & Percentage of variance & 29.872 & 2.549 & 1.662 & 1.288 & 1.056 & - & - \\
\cline { 2 - 8 } & Cumulative \% & 29.854 & 43.272 & 52.020 & 58.800 & 64.356 & - & - \\
\hline & Total & 3.455 & 3.324 & 2.228 & 1.660 & 1.560 & - & - \\
\hline & Percentage of variance & 18.186 & 17.497 & 11.728 & 8.737 & 8.208 & - & - \\
\hline
\end{tabular}

Table 3 provides the eigenvalues of the correlation matrix obtained through the factor analysis method and the contribution rate of the corresponding variables. In general, if the contribution rate of each factor accumulation variance is more than $60 \%$, then the scale can be considered to have good results. The results of this study reach $64.36 \%$, which meet the requirements. The five largest eigenvalues are $5.672,2.549,1.662,1.288$ and 1.056 , respectively, and the corresponding weights are $0.299,0.134,0.088,0.068$, and 0.056 , respectively. When we selected five common factors, their cumulative contribution rate reached $64.36 \%$. However, if the selection variables are constructed properly under following analysis steps, most information of the selected indicators can be reflected. The comprehensive evaluation index function can be obtained as follows:

$\mathrm{F}=29.854 * \mathrm{~F} 1 /(64.36)+13.418 * \mathrm{~F} 2 /(64.36)+8.748 * \mathrm{~F} 3 /(64.36$ )$+6.78 * \mathrm{~F} 4 /(64.36)+5.556 * \mathrm{~F} 5 /(64.36)$

\subsubsection{Rotation factor}

The rotation factor loading matrix, which was obtained using the orthogonal rotation method with maximum variance, is shown in Table 4.

Table 4. Rotating component matrix

\begin{tabular}{cccccc|rccccc}
\hline \multicolumn{7}{c}{ Component } & \multicolumn{5}{c}{ Component } \\
\hline Indicator & $\mathbf{1}$ & $\mathbf{2}$ & $\mathbf{3}$ & $\mathbf{4}$ & $\mathbf{5}$ & Indicator & $\mathbf{1}$ & $\mathbf{2}$ & $\mathbf{3}$ & $\mathbf{4}$ & $\mathbf{5}$ \\
\hline $\mathrm{X}_{1}$ & 0.863 & 0.080 & 0.078 & 0.045 & 0.028 & $\mathrm{X}_{11}$ & 0.168 & 0.715 & 0.052 & 0.124 & 0.021 \\
\hline $\mathrm{X}_{2}$ & 0.900 & 0.173 & 0.059 & 0.032 & 0.013 & $\mathrm{X}_{12}$ & 0.218 & 0.411 & 0.434 & 0.238 & -0.010 \\
\hline $\mathrm{X}_{3}$ & 0.854 & 0.138 & 0.074 & 0.015 & 0.030 & $\mathrm{X}_{13}$ & 0.119 & 0.626 & 0.360 & 0.150 & 0.131 \\
\hline $\mathrm{X}_{4}$ & 0.785 & 0.264 & -0.017 & 0.000 & 0.028 & $\mathrm{X}_{14}$ & 0.080 & 0.312 & 0.688 & 0.238 & 0.078 \\
\hline $\mathrm{X}_{5}$ & 0.596 & -0.073 & 0.135 & 0.445 & -0.009 & $\mathrm{X}_{15}$ & 0.183 & 0.351 & 0.579 & -0.041 & 0.250 \\
\hline $\mathrm{X}_{6}$ & 0.045 & 0.340 & 0.031 & 0.808 & 0.012 & $\mathrm{X}_{16}$ & -0.068 & -0.022 & 0.728 & 0.268 & 0.085 \\
\hline $\mathrm{X}_{7}$ & 0.118 & 0.446 & 0.186 & 0.678 & 0.022 & $\mathrm{X}_{17}$ & 0.056 & 0.051 & 0.666 & -0.183 & -0.045 \\
\hline $\mathrm{X}_{8}$ & 0.133 & 0.712 & 0.090 & 0.205 & -0.100 & $\mathrm{X}_{19}$ & 0.110 & 0.028 & 0.051 & -0.092 & 0.833 \\
\hline $\mathrm{X}_{9}$ & 0.058 & 0.738 & 0.021 & 0.140 & 0.085 & $\mathrm{X}_{20}$ & -0.060 & 0.063 & 0.108 & 0.125 & 0.864 \\
\hline $\mathrm{X}_{10}$ & 0.099 & 0.726 & 0.185 & 0.027 & 0.050 & - & & & & & \\
\hline
\end{tabular}


Table 5. Indicators of various factors

\begin{tabular}{|c|c|c|c|c|}
\hline \multirow[b]{2}{*}{ Common factor } & \multirow[b]{2}{*}{ Variables } & \multicolumn{3}{|c|}{ Extract the sum of squared loads } \\
\hline & & Total & $\begin{array}{c}\text { Percentage of } \\
\text { variance }\end{array}$ & Cumulative $\%$ \\
\hline F1 (convenient transportation factor) & $\mathrm{X}_{1}, \mathrm{X}_{2}, \mathrm{X}_{3}, \mathrm{X}_{4}, \mathrm{X}_{5}$ & 5.672 & 29.854 & 29.854 \\
\hline F2 (public environmental factor) & $\mathrm{X}_{8}, \mathrm{X}_{9}, \mathrm{X}_{10}, \mathrm{X}_{11}, \mathrm{X}_{12}, \mathrm{X}_{13}$ & 2.549 & 13.418 & 43.272 \\
\hline F3 (residential safety and comfort factor) & $\mathrm{X}_{14}, \mathrm{X}_{15}, \mathrm{X}_{16}, \mathrm{X}_{17}$ & 1.662 & 8.748 & 52.020 \\
\hline F4 (good road factor) & $\mathrm{X}_{6}, \mathrm{X}_{7}$ & 1.288 & 6.780 & 58.800 \\
\hline F5 (traffic and crime factor) & $\mathrm{X}_{19}, \mathrm{X}_{20}$ & 1.056 & 5.556 & 64.356 \\
\hline
\end{tabular}

We can observe the following (common feature-naming factors based on the variables contained in each factor) from the rotation factor loading matrix.

\section{(1) F1 (Convenient transportation factor)}

The variance contribution rate of the convenient transportation factor is the highest among the five public factors. This factor consists of "convenient to go to school", "convenient to go to the market", "convenient to go to the city", "convenient to go to the public transportation station" and "convenient to go to the health center". Thus, it was appropriately called the convenient transportation factor. This factor explained $29.85 \%$ (Table 5) of all the variables, and therefore, should be given more attention.

(2) F2 (Public environmental factor)

The variance contribution rate of the public environmental factor is second to that of the convenient transportation factor, explaining $13.42 \%$ of all the variables in the sample. This factor consists of six variables, namely, "parks or other public open spaces are found near homes", "a spacious public courtyard", "sufficient parking", "complete road lighting", "attractive village appearance" and "maintenance service for public facilities". Most of the factors involved represent the public environment, and thus, this factor was called the public environmental factor.

(3) F3 (Residential safety and comfort factor)

This factor explained $8.75 \%$ of all the variables in the sample. It consists of "walking outside is safe", "safe for children to play outside", "living environment is quiet" and "neighbors frequently chat with one another".

\section{(4) F4 (Good road factor)}

The construction of rural roads is increasing daily. Township roads have adopted the standard of four-level highways or higher. The length of fourth-grade roads increased from $50,166 \mathrm{~km}$ in 2004 to $229,637 \mathrm{~km}$ in 2015 . The length of off-grade roads increased from $21,152 \mathrm{~km}$ in 2000 to $49,518 \mathrm{~km}$ in 2015 , which indicated an increase of $28,366 \mathrm{~km}$ in 15 years. With regard to the survey site, the contribution of the good road factor is $6.78 \%$. This factor is composed of "good bike paths" and "good walkway". The favorable condition of roads directly affects the movement of rural residents.

\section{(5) F5 (Traffic and crime factor)}

This factor explained $5.56 \%$ of all the variables in the sample. The items for this factor include "no crime occurs near in the neighbourhood" and "no traffic accident occurs in the neighbourhood" and thus, this factor was directly called traffic and crime factor. It ranks last among the five explanatory factors.

\subsubsection{Built environment satisfaction calculation}

Satisfaction is used to explain the built environment perception. Based on the factor loading matrix in Table 4, the factor score function is estimated using the least squares method. The score matrix is provided in Table 6.

Table 6. Factor score coefficient matrix

\begin{tabular}{rccccc|rccccc}
\hline \multicolumn{7}{c}{ Component } & \multicolumn{6}{c}{ Component } \\
\hline Indicator & $\mathbf{1}$ & $\mathbf{2}$ & $\mathbf{3}$ & $\mathbf{4}$ & $\mathbf{5}$ & Indicator & $\mathbf{1}$ & $\mathbf{2}$ & $\mathbf{3}$ & $\mathbf{4}$ & $\mathbf{5}$ \\
\hline $\mathrm{X}_{1}$ & 0.275 & -0.066 & 0.002 & -0.020 & 0.002 & $\mathrm{X}_{11}$ & -0.017 & 0.287 & -0.102 & -0.080 & -0.014 \\
\hline $\mathrm{X}_{2}$ & 0.279 & -0.018 & -0.022 & -0.053 & -0.010 & $\mathrm{X}_{12}$ & 0.014 & 0.050 & 0.163 & 0.046 & -0.066 \\
\hline $\mathrm{X}_{3}$ & 0.268 & -0.029 & -0.007 & -0.058 & 0.001 & $\mathrm{X}_{13}$ & -0.035 & 0.190 & 0.081 & -0.063 & 0.030 \\
\hline $\mathrm{X}_{4}$ & 0.236 & 0.055 & -0.077 & -0.088 & 0.006 & $\mathrm{X}_{14}$ & -0.030 & -0.027 & 0.323 & 0.052 & -0.031 \\
\hline $\mathrm{X}_{5}$ & 0.185 & -0.217 & 0.033 & 0.346 & -0.012 & $\mathrm{X}_{15}$ & 0.012 & 0.060 & 0.256 & -0.173 & 0.089 \\
\hline $\mathrm{X}_{6}$ & -0.046 & -0.040 & -0.117 & 0.574 & 0.014 & $\mathrm{X}_{16}$ & -0.051 & -0.187 & 0.400 & 0.158 & -0.018 \\
\hline $\mathrm{X}_{7}$ & -0.032 & 0.010 & -0.032 & 0.425 & -0.004 & $\mathrm{X}_{17}$ & 0.003 & -0.042 & 0.407 & -0.229 & -0.114 \\
\hline $\mathrm{X}_{8}$ & -0.031 & 0.268 & -0.072 & -0.019 & -0.098 & $\mathrm{X}_{19}$ & 0.029 & -0.011 & -0.064 & -0.069 & 0.555 \\
\hline $\mathrm{X}_{9}$ & -0.055 & 0.307 & -0.130 & -0.064 & 0.034 & $\mathrm{X}_{20}$ & -0.040 & -0.040 & -0.056 & 0.102 & 0.576 \\
\hline $\mathrm{X}_{10}$ & -0.041 & 0.300 & -0.017 & -0.171 & -0.012 & - & & & & & \\
\hline
\end{tabular}


To avoid confusion, the standardized built environment perception indicator $\mathrm{Y} 1$ is used to represent $\mathrm{X} 1$ (Y2 is used to represent $\mathrm{X} 2$, and others in the same way) in the questionnaire. The mathematical expression is as follows:

$\mathrm{F} 1=0.275 * \mathrm{Y} 1+0.279 * \mathrm{Y} 2+0.268 * \mathrm{Y} 3+0.236 * \mathrm{Y} 4+0.185 * \mathrm{Y} 5-$ $0.046 * \mathrm{Y} 6-0.032 * \mathrm{Y} 7-0.031 * \mathrm{Y} 8-0.055 * \mathrm{Y} 9-0.041 * \mathrm{Y} 10-$ $0.017 * \mathrm{Y} 11+0.014 * \mathrm{Y} 12-0.035 * \mathrm{Y} 13-0.03 * \mathrm{Y} 14+0.012 * \mathrm{Y} 15-$ $0.051 * \mathrm{Y} 16+0.003 * \mathrm{Y} 17+0.029 * \mathrm{Y} 19-0.04 * \mathrm{Y} 20$,

$\mathrm{F} 2=-0.066 * \mathrm{Y} 1-0.018 * \mathrm{Y} 2-0.029 * \mathrm{Y} 3+0.055 * \mathrm{Y} 4-0.217 * \mathrm{Y} 5-$ $0.04 * \mathrm{Y} 6+0.01 * \mathrm{Y} 7+0.268 * \mathrm{Y} 8+0.307 * \mathrm{Y} 9+0.3 * \mathrm{Y} 10+0.287 *$ $\mathrm{Y} 11+0.05 * \mathrm{Y} 12+0.19 * \mathrm{Y} 13-0.027 * \mathrm{Y} 14+0.06 * \mathrm{Y} 15-$ $0.187 * \mathrm{Y} 16-0.042 * \mathrm{Y} 17-0.011 * \mathrm{Y} 19-0.04 * \mathrm{Y} 20$,

$\mathrm{F} 3=0.002 * \mathrm{Y} 1-0.022 * \mathrm{Y} 2-0.007 * \mathrm{Y} 3-0.077 * \mathrm{Y} 4+0.033 * \mathrm{Y} 5-$ $0.117 * \mathrm{Y} 6-0.032 * \mathrm{Y} 7-0.072 * \mathrm{Y} 8-0.13 * \mathrm{Y} 9-0.017 * \mathrm{Y} 10-$ $0.102 * \mathrm{Y} 11+0.163 * \mathrm{Y} 12+0.081 * \mathrm{Y} 13+0.323 * \mathrm{Y} 14+0.256 * \mathrm{Y}$ $15+0.4 * \mathrm{Y} 16+0.407 * \mathrm{Y} 17-0.064 * \mathrm{Y} 19-0.056 * \mathrm{Y} 20$,

$\mathrm{F} 4=-0.02 * \mathrm{Y} 1-0.053 * \mathrm{Y} 2-0.058 * \mathrm{Y} 3-$ $0.088 * \mathrm{Y} 4+0.346 * \mathrm{Y} 5+0.574 * \mathrm{Y} 6+0.425 * \mathrm{Y} 7-0.019 * \mathrm{Y} 8-$ $0.064 * \mathrm{Y} 9-0.171 * \mathrm{Y} 10-0.08 * \mathrm{Y} 11+0.046 * \mathrm{Y} 12-$ $0.063 * \mathrm{Y} 13+0.052 * \mathrm{Y} 14-0.173 * \mathrm{Y} 15+0.158 * \mathrm{Y} 16-$ $0.229 * \mathrm{Y} 17-0.069 * \mathrm{Y} 19+0.102 * \mathrm{Y} 20$,

$\mathrm{F} 5=0.002 * \mathrm{Y} 1-0.01 * \mathrm{Y} 2+0.001 * \mathrm{Y} 3+0.006 * \mathrm{Y} 4-$ $0.012 * \mathrm{Y} 5+0.014 * \mathrm{Y} 6-0.004 * \mathrm{Y} 7-0.098 * \mathrm{Y} 8+0.034 * \mathrm{Y} 9$ $0.012 * \mathrm{Y} 10-0.014 * \mathrm{Y} 11-0.066 * \mathrm{Y} 12+0.03 * \mathrm{Y} 13-$ $0.031 * \mathrm{Y} 14+0.089 * \mathrm{Y} 15-0.018 * \mathrm{Y} 16-$ $0.114 * \mathrm{Y} 17+0.555 * \mathrm{Y} 19+0.576 * \mathrm{Y} 20$.

When the values of F1, F2, F3, F4 and F5 are substituted into (1), the overall satisfaction is $F=2.906$. When $F=2.906$ is converted into percentage, the built environment satisfaction of rural residents in this survey is $58.12 \%$. Overall, satisfaction is low.

\subsection{Built environment preference}

Factor analysis was used to investigate the built environment preference part of the questionnaire. The KMO coefficient of sample sufficiency is 0.883 , the empirical value is greater than 0.5 , and significance is $P=0.000$. The analysis shows that the first five principal component eigenvalues are greater than 1 , and their cumulative contribution rate reaches $69.56 \%$. Hence, the first five common factors were selected. The rotation factor loading matrix, which was obtained using the orthogonal rotation method with maximum variance, is shown in Table 7.

\subsubsection{Common factor extraction}

Factor analysis was used to extract common factors. The specific operation results are presented in Table 8 .

Table 8 lists the eigenvalues of the correlation matrix obtained through factor analysis and the contributions of the corresponding variables. The maximum five eigenvalues are $8.141,2.068,1.607,1.888$ and 1.008 , respectively, and their corresponding weights are $0.407,0.103,0.080,0.054$ and 0.050 , respectively. The comprehensive evaluation index function can be obtained as follows:

$\mathrm{F}=40.706 * \mathrm{~F} 1{ }^{\prime} /(69.56)+10.341 * \mathrm{~F} 2 \% /(69.56)+8.036 * \mathrm{~F} 3 \% /(69$. $56)+5.438 * \mathrm{~F} 4 \%(69.56)+5.041 * \mathrm{~F} 5 \%(69.56)$

Common feature-naming factors based on the variables contained in each factor.

(1) F1' (Travel safety factor)

The travel safety factor (F1') under built environment preference analysis explained $40.71 \%$ (Table 9) of all the variables. This factor exerts the greatest effect on the built environment preference and a safe environment without crime is widely believed to be the primary consideration for living. People can only live satisfactorily when their safety is ensured, which is in line with the requirements of residents when choosing their place of residence.

(2) F2' (Convenient transportation factor)

The convenient transportation factor explains $10.34 \%$ of all the variables. This factor consists of "convenient to go to school", "convenient to go to the market", "convenient to go to the city", "convenient for public transportation" and "convenient to go to the health center". This factor ranks second.

Table 7. Rotating component matrix

\begin{tabular}{cccccc|cccccc}
\hline \multicolumn{7}{c}{ Component } & \multicolumn{6}{c}{ Component } \\
\hline Indicator & $\mathbf{1}$ & $\mathbf{2}$ & $\mathbf{3}$ & $\mathbf{4}$ & $\mathbf{5}$ & Indicator & $\mathbf{1}$ & $\mathbf{2}$ & $\mathbf{3}$ & $\mathbf{4}$ & $\mathbf{5}$ \\
\hline $\mathrm{X}_{1}$ & 0.222 & 0.792 & 0.153 & 0.036 & -0.064 & $\mathrm{X}_{11}$ & 0.454 & 0.102 & 0.627 & 0.042 & 0.210 \\
\hline $\mathrm{X}_{2}$ & 0.162 & 0.865 & 0.146 & 0.071 & 0.131 & $\mathrm{X}_{12}$ & 0.498 & 0.078 & 0.485 & 0.373 & 0.192 \\
\hline $\mathrm{X}_{3}$ & 0.088 & 0.845 & 0.122 & 0.210 & 0.159 & $\mathrm{X}_{13}$ & 0.362 & 0.103 & 0.397 & 0.200 & 0.537 \\
\hline $\mathrm{X}_{4}$ & 0.067 & 0.661 & 0.136 & 0.341 & 0.244 & $\mathrm{X}_{14}$ & 0.775 & 0.222 & 0.273 & -0.076 & 0.164 \\
\hline $\mathrm{X}_{5}$ & 0.209 & 0.513 & 0.087 & 0.416 & 0.255 & $\mathrm{X}_{15}$ & 0.802 & 0.188 & 0.139 & -0.104 & 0.094 \\
\hline $\mathrm{X}_{6}$ & -0.061 & 0.292 & 0.295 & 0.703 & 0.268 & $\mathrm{X}_{16}$ & 0.478 & 0.116 & 0.290 & 0.062 & 0.514 \\
\hline $\mathrm{X}_{7}$ & 0.166 & 0.264 & 0.257 & 0.686 & 0.172 & $\mathrm{X}_{17}$ & 0.253 & 0.094 & 0.272 & 0.193 & 0.683 \\
\hline $\mathrm{X}_{8}$ & 0.132 & 0.198 & 0.658 & 0.438 & 0.079 & $\mathrm{X}_{18}$ & -0.005 & 0.195 & 0.069 & 0.148 & 0.812 \\
\hline $\mathrm{X}_{9}$ & -0.011 & 0.212 & 0.773 & 0.136 & 0.242 & $\mathrm{X}_{19}$ & 0.716 & 0.130 & 0.004 & 0.478 & 0.083 \\
\hline $\mathrm{X}_{10}$ & 0.214 & 0.120 & 0.763 & 0.113 & 0.110 & $\mathrm{X}_{20}$ & 0.718 & 0.115 & 0.094 & 0.463 & 0.089 \\
\hline
\end{tabular}


Table 8 . Total variance interpretation

\begin{tabular}{llrrrrrr}
\hline & Variance & \multicolumn{5}{c}{ Component } \\
\cline { 3 - 7 } & & $\mathbf{1}$ & $\mathbf{2}$ & $\mathbf{3}$ & $\mathbf{4}$ & $\mathbf{5}$ & $\mathbf{6}$ \\
\hline \multirow{3}{*}{\begin{tabular}{l} 
Initial eigenvalue \\
\cline { 2 - 7 }
\end{tabular}} & Total & 8.141 & 2.068 & 1.607 & 1.088 & 1.008 & 0.837 \\
\cline { 2 - 7 } & Percentage of variance & 40.706 & 10.341 & 8.036 & 5.438 & 5.041 & 4.183 \\
\cline { 2 - 7 } $\begin{array}{l}\text { Extract the sum of } \\
\text { squared loads }\end{array}$ & Cumulative \% & 40.706 & 51.048 & 59.084 & 64.522 & 69.564 & 73.747 \\
\hline & Potal & 8.141 & 2.068 & 1.607 & 1.088 & 1.008 & - \\
\hline \multirow{2}{*}{$\begin{array}{l}\text { Sum of squared } \\
\text { rotational loads }\end{array}$} & Cumulative \% & 40.706 & 10.341 & 8.036 & 5.438 & 5.041 & - \\
\hline & Total & 40.706 & 51.048 & 59.084 & 64.522 & 69.564 & - \\
\cline { 2 - 7 } & Percentage of variance & 16.874 & 16.222 & 14.511 & 11.155 & 10.801 & - \\
\cline { 2 - 7 } & Cumulative \% & 16.874 & 33.096 & 47.607 & 58.763 & 69.564 & - \\
\hline
\end{tabular}

Table 9. Indicators of various factors

\begin{tabular}{llccc}
\hline \multirow{2}{*}{ Common factor } & Variables & \multicolumn{2}{c}{ Extract the sum of squared loads } \\
\cline { 3 - 5 } & & Total & $\begin{array}{c}\text { Percentage of } \\
\text { variance }\end{array}$ & Cumulative \% \\
\hline F1' (travel safety factor) & $\mathrm{X}_{14}, \mathrm{X}_{15}, \mathrm{X}_{19}, \mathrm{X}_{20}$ & 8.141 & 40.706 & 40.706 \\
\hline F2' ((convenient transportation factor) & $\mathrm{X}_{1}, \mathrm{X}_{2}, \mathrm{X}_{3}, \mathrm{X}_{4}, \mathrm{X}_{5}$ & 2.068 & 10.341 & 51.048 \\
\hline F3' (public environmental factor) & $\mathrm{X}_{8}, \mathrm{X}_{9}, \mathrm{X}_{10}, \mathrm{X}_{11}, \mathrm{X}_{12}, \mathrm{X}_{13}$ & 1.607 & 8.036 & 59.084 \\
\hline F4' (good road factor) & $\mathrm{X}_{6}, \mathrm{X}_{7}$ & 1.088 & 5.438 & 64.522 \\
\hline F5' (neighborhood harmony factor) & $\mathrm{X}_{16}, \mathrm{X}_{17}, \mathrm{X}_{18}$ & 1.008 & 5.041 & 69.564 \\
\hline
\end{tabular}

\section{(3) F3' (Public environmental factor)}

This factor's variance contribution rate is $8.04 \%$. It consists of "parks or other public open spaces near homes", "a spacious public courtyard", "adequate parking lots", "road lighting facilities", "attractive village appearance" and "efficient facility repair service."

(4) F4' (Good road factor)

The good road factor is composed of "a good bike path" and "a good walkway". Its variance contribution rate is $5.44 \%$. This factor ranks fourth among all the factors.

(5) F5' (Neighborhood harmony factor)

The variance contribution rate of the neighborhood harmony factor is $5.04 \%$. This factor consists of "living environment is quiet", "neighbors frequently chat with one another" and "no difference in family economic conditions among neighbors". This factor ranks last, thereby indicating that neighborhood condition is not a primary consideration of rural residents when choosing their new homes.

\subsubsection{Built environmental importance calculation}

The degree to which rural residents prefer the built environment is illustrated in terms of importance. The score matrix is provided in Table 10.

The calculation method is the same as that for built environment satisfaction:

$\mathrm{F} 1^{\prime}=3.50, \mathrm{~F}^{\prime}=3.44, \mathrm{~F}^{\prime}=2.66, \mathrm{~F}^{\prime}{ }^{\prime}=1.85$ and $\mathrm{F} 5^{\prime}=2.25$.
When the values of F1', F2', F3', F4' and F5' are substituted into (2), the degree of importance is $F=3.17$ and the percentage is $63.46 \%$.

\section{Analysis of the Built Environment Perception and Preference of Rural Residents}

\subsection{Built environment perception}

From the factor analysis, the 20 indicators of rural residents' perception of the built environment can be summarized into 5 aspects: convenient transportation, public environment, residential safety and comfort, good road, traffic and crime. The following conclusions can be drawn from the analysis.

(1) In the process of building the new countryside, rural residents have higher appreciation of convenient transportation, clinics and shops. Bus stations should not be far from the village. Even no school is located in the village, as long as traffic is good, respondents still believe that it will be convenient for children to go to school. Comparing the convenient transportation factor with the other four factors, the variance contribution rate reached $29.85 \%$, thereby indicating that this factor has the strongest explanatory power and is the key factor that affects rural residents' perception of the built environment. Moreover, improving the degree of traffic convenience will result in rural residents' satisfaction with the existing built environment. 
(2) Judging from rural residents' perception of the built environment, public activity spaces should be expanded in rural areas and road lighting and public facilities should be improved. Rural residents can organize their activities freely in public spaces. Rural residents are satisfied with the public environment.

(3) The existing environment in rural areas is comfortable for local residents. The residents of the surveyed area can appreciate village appearance. They feel that the environment where they live is relatively safe, but still has room for improvement.
(4) People are more willing to live in places where roads are built well. Although the construction of rural roads is increasing daily, bicycle lanes and sidewalks are ranked lower. Hence, the construction of rural roads should be improved.

(5) Rural residents indicated a lack of traffic accident and crime. During the survey, residents mentioned many traffic accidents around the neighbourhood, which is related to the regional planning of the study area. Houses are built on the side of roads, which poses a threat to residents' safety. The lack of rural surveillance and guards may lead to crimes.

Table 10. Component score coefficient matrix

\begin{tabular}{rccccc|rccccc}
\hline \multicolumn{7}{c}{ Ingredient } & \multicolumn{5}{c}{ Ingredient } \\
\hline Indicator & $\mathbf{1}$ & $\mathbf{2}$ & $\mathbf{3}$ & $\mathbf{4}$ & $\mathbf{5}$ & Indicator & $\mathbf{1}$ & $\mathbf{2}$ & $\mathbf{3}$ & $\mathbf{4}$ & $\mathbf{5}$ \\
\hline $\mathrm{X}_{1}$ & 0.034 & 0.343 & 0.029 & -0.148 & -0.171 & $\mathrm{X}_{11}$ & 0.081 & -0.038 & 0.275 & -0.153 & -0.030 \\
\hline $\mathrm{X}_{2}$ & -0.018 & 0.360 & -0.018 & -0.165 & -0.019 & $\mathrm{X}_{12}$ & 0.106 & -0.105 & 0.128 & 0.137 & -0.075 \\
\hline $\mathrm{X}_{3}$ & -0.058 & 0.328 & -0.051 & -0.047 & -0.008 & $\mathrm{X}_{13}$ & 0.032 & -0.073 & 0.044 & -0.043 & 0.263 \\
\hline $\mathrm{X}_{4}$ & -0.075 & 0.212 & -0.069 & 0.075 & 0.050 & $\mathrm{X}_{14}$ & 0.282 & 0.044 & 0.024 & -0.221 & -0.010 \\
\hline $\mathrm{X}_{5}$ & 0.000 & 0.123 & -0.128 & 0.160 & 0.052 & $\mathrm{X}_{15}$ & 0.325 & 0.044 & -0.043 & -0.205 & -0.032 \\
\hline $\mathrm{X}_{6}$ & -0.157 & -0.030 & 0.007 & 0.408 & 0.011 & $\mathrm{X}_{16}$ & 0.109 & -0.040 & -0.014 & -0.140 & 0.279 \\
\hline $\mathrm{X}_{7}$ & -0.037 & -0.044 & -0.026 & 0.410 & -0.076 & $\mathrm{X}_{17}$ & -0.013 & -0.073 & -0.050 & -0.045 & 0.420 \\
\hline $\mathrm{X}_{8}$ & -0.083 & -0.041 & 0.300 & 0.178 & -0.186 & $\mathrm{X}_{18}$ & -0.116 & 0.000 & -0.167 & -0.075 & 0.594 \\
\hline $\mathrm{X}_{9}$ & -0.164 & 0.013 & 0.407 & -0.102 & -0.014 & $\mathrm{X}_{19}$ & 0.278 & -0.080 & -0.207 & 0.296 & -0.102 \\
\hline $\mathrm{X}_{10}$ & -0.041 & -0.028 & 0.405 & -0.091 & -0.129 & $\mathrm{X}_{20}$ & 0.266 & -0.090 & -0.148 & 0.271 & -0.113 \\
\hline
\end{tabular}

\subsection{Comparative analysis of perception and preference}

This study defines rural residents' satisfaction with the present living environment as the perception of the built environment. The preference for the built environment is regarded as the degree of influence of different environmental factors on rural residents' choice of a new residence in the new rural development process. Comparing the perceptions and preferences of the built environment in Tables 5 and 9, the three common factors are convenient transportation, public environment and good roads. These factors affect the perception and preference of rural residents. However, the importance of each factor varies in different situations. In the analysis, convenient transportation and public environmental factors ranks first and second in the built environment perception, respectively. However, these factors ranks second and third in the built environment preference, respectively. Residents feel that traveling is convenient, destinations are easily accessible, and the surrounding facilities and activity spaces are good. However, this factor is not the most important in built environment preference. The data analysis shows that travel safety is the most important consideration for rural residents. In the analysis of built environment preference, F1' ranks first. Therefore, security is lacking in the existing built environment. Traffic accidents and crimes still occur. The factor that includes traffic accidents and crimes in built environment perception is ranked as the last. If traffic accidents and crimes are reduced, then satisfaction with the built environment will be improved considerably. The good road factor ranks fourth in built environment perception and preference, thereby indicating that although bicycle lanes and sidewalks should be improved in the existing built environment, people's expectations for roads are general. A single-use road can no longer meet the needs of rural residents. The development of new rural areas has driven the development of farmers' economy. Rural residents have increased their means of travel and expect a larger number of good bicycle lanes and sidewalks. The rapid development of urbanization may result in a certain gap between the rich and the poor. Rural residents will be more willing to live in places with less economic disparities.

\section{Conclusion}

This study uses factor analysis to compare the factors of built environment perception and preference of rural residents. The following conclusions are drawn.

Firstly, the needs of rural residents for their living environment should be ensured in the rapid construction of new rural areas and their feelings on the surrounding built environment should be considered. Subsequently, humanized designs should be part of the new rural planning and construction process. In the transition from traditional to 
new rural areas, the living environment will undergo major changes. Rural residents must be considered in terms of their perception and preference for their built environment to meet their needs fully and improve the satisfaction and quality of life of farmers.

Secondly, rural residents regarded safety, comfort and public security as the primary consideration factors for their place of residence. In the process of building a new countryside, the problem has been improved compared with the environmental safety and security issues of the previous residences. The residents of the surveyed areas are still satisfied with local security. Hence, safety, comfort and security can be improved. Such improvement requires the government to increase public security monitoring to ensure the safety of rural residents.

Thirdly, the travel condition of rural residents should be improved. The difficulties in entering a city in traditional rural areas, going to school and to the market, and seeing a doctor should be resolved. The new countryside should have smooth roads, sufficient street lamps to ensure safety at night, community medical centers to solve the problem of difficulty in getting medical treatment, convenience stores to solve the problem of farmers purchasing daily necessities, and schools in the village to solve the problem of children going to school. These factors should be considered in new rural road network planning.

Fourthly, public space in traditional rural areas is large and provides rural residents with sufficient areas for activities and entertainment. In the construction of the new countryside, sufficient public space should be considered to provide daily entertainment and areas where rural residents can congregate and socialize. Street lamps and leisure facilities should also be provided in public spaces. Rural residents will not only feel the natural scenery as before but will also enjoy the modern atmosphere in the new countryside.

\section{References}

Berke, E.M., T.D. Koepsell, A.V. Moudon and R.E. Hoskins, 2007. Association of the built environment with physical activity obesity in older persons. American Journal of Public Health, 97(3): 486 - 492.

Cervero, R. and K. Kockelman, 1997. Travel demand and the 3Ds: density, diversity, and design. Transp. Res. Part D 2(3): 199 - 219.

Cervero, R. and K.L. Wu, 1998. Sub-centring and commuting: evidence from the San Francisco Bay Area, 1980-90. Urban Studies, 35(7): 1059 - 1076.

Chen, C.G., 2014. On the dialectical relationship between new urbanization and new rural construction. Social Sciences, 3: 48 - 52.

Cheng, B.D., 2011. Two types of "three rural" problems in China and a new rural construction concept. China Rural Economy, 8: 4 - 11 .
Dong, J.G., Y.Z. Feng, Y.Q. Bao, S.B. Zhou, X. Zhou, Y. Zhang and Z.G. Liu, 2011. Analysis of subjective evaluation based on built environment. Journal of Xi'an University of Architecture \& Technology (Natural Science Edition), 43(5): 694 - 699.

Ewing, R. and R. Cervero, 2001. Travel and the built environment: a synthesis. Transp. Res. Rec. 1780: 87 114.

Ewing, R. and R. Cervero, 2010. Travel and the built environment: a meta-analysis. J. Am. Plan. Assoc. 76(3): $265-294$.

Ewing, R., M.J. Greenwald, M. Zhang, J. Walters, M. Feldman, R. Cervero and J. Thomas, 2009. Measuring the impact of rrban form and transit access on mixed use site trip generation rates. Portland Pilot Study. U.S. Environmental Protection Agency, Washington, DC.

Hong, J., Q. Shen and L. Zhang, 2014. How do built environment factors affect travel behavior? A spatial analysis at different geographic scales. Transportation, 41(3): 419 - 440.

Ji, J. and Y. Long, 2010. Study on the questionnaire survey of new rural cooperatives based on factor analysis. Technology Economics, 29(8): 110 - 115.

Sun, B.D. and B. Dan, 2015. The influence of Shanghai urban built environment on residents' commuting choices. Acta Geographica Sinica,70(10): 1664 - 1674.

Ta, N., Y.W. Chai and M.B. Guan, 2015. The influence of urban built environment on the choice of car travel in the working days of residents in Beijing suburbs. Acta Geographica Sinica,70(10): 1675 - 1685.

Wang, D. and M. Zhou, 2017. The built environment and travel behavior in urban China: a literature review. Transportation Research Part D: Transport and Environment, 52: 574 - 585.

Wu, S., 2014. A book of SPSS statistical analysis. Beijing: Tsinghua University Press.

Wu, Y., 2017. Research on the impact of built environment on residents' walking behavior. Master's Thesis. Jiangxi Normal University.

Yang, Q, H.Z. Yang and S.M. Feng, 2014. Characteristics of rural residents' trips under different economic conditions. Journal of Chang'an University (Natural Science Edition), 34(1): 76 - 83.

Zhang, Y.J., B. Qin and J. Tang, 2017. The impact of urban built environment on residential safety sense-based on empirical analysis of 278 urban communities in China. Geography Science, 37(9): 1318 - 1325.

Zhou, Y., H.Z. Wang and G.T. Chi, 2016. A model and empirical study of green industry evaluation index system based on factor analysis. Journal of Systems Management, 25(2): 338 - 352. 